\title{
TINJAUAN YURIDIS TERHADAP PERAN DAN FUNGSI ADVOKAT DALAM PENYELESAIAN PERKARA PERDATA
}

\author{
Darwis Manurung \\ Fakultas Hukum Universitas Borneo Tarakan \\ Jalan Amal Lama No.1. Tarakan \\ darwismanurung@yahoo.co.id
}

\begin{abstract}
Abstrak
Advokat adalah orang memenuhi persyaratan sesuai ketentuan perundang undangan yang berprofesi untuk memberikan jasa hukum baik di dalam maupun di luar Pengadilan. Peran seorang advokat dalam memberikan layanan hukum dalam perkara perdata adalah bahwa Advokat sebagai penerima kuasa dari pihak penggugat atau tergugat untuk mewakili dalam beracara di depan Pengadilan untuk menjelaskan dan meluruskan fakta dan bukti yang diajukan oleh klien, sehingga mereka dapat membantu dan memfasilitasi hakim dalam mengambil keputusan.

Dalam menjalankan fungsinya dan perananya dalam perkara perdata selaku kuasa hukum wajib menjalankan kode etiknya profesi selaku Advokat. Pekerjaan advokat atau kuasa hukum adalah pekerjaan atas dasar kepercayaan. Demikianlah hubungan antara advokat dengan klien harus diawali dengan hubungan kepercayaan. Sehingga hubungan antara kuasa hukum dengan klien dapat berjalan sesuai dengan kode etik yang telah ditentukan untuk profesi advokat. Para advokat dalam melaksanakan tugas-tugas profesinya dilarang untuk membedakan klien berdasarkan gender, agama, ras, keturunan, politik, atau latar belakang sosial dan budaya.
\end{abstract}

Kata kunci: advokat, penyelesaian perkara perdata

\begin{abstract}
Advocates are people who fulfill the requirements in accordance with statutory provisions that work to provide legal services both inside and outside the Court. The role of an advocate in providing legal services in civil matters is that the Advocate as the proxy of the plaintiff or the defendant to represent the proceedings in front of the Court to explain and straighten the facts and evidence submitted by the client, so that they can assist and facilitate the judge in making decisions.

In carrying out its functions and its role in civil cases as attorneys must carry out the professional code of ethics as Advocates. The work of an advocate or attorney is work based on trust. Thus the relationship between advocates and clients must begin with a trust relationship. So that the relationship between attorneys and clients can run in accordance with the code of ethics that has been determined for the advocate profession. Advocates in carrying out their professional duties are prohibited from distinguishing clients based on gender, religion, race, descent, politics, or social and cultural background.
\end{abstract}

Keywords: advocate, settlement of civil matters 


\section{A. PENDAHULUAN}

Pesatnya perkembangan masyarakat dan semakin kompleksnya relasi yang terjalin diantara mereka, baik di bidang sosial maupun ekonomi, perlu diikuti dengan berbagai aturan hukum guna menjaga ketertiban dalam relasi tersebut. Benturan kepentingan dalam pergaulan social sangat rawan akan terjadi antar sesama warga masyarakat. Rumitnya aturan hukum yang berlaku membuat aturan hukum tersebut tidak mudah dipahami oleh masyarakat. Dalam negara yang berdasarkan hukum maka segala benturan kepentingan atau perselisihan hukum yang terjadi harus diselesaikan secara hukum melalui jalur Pengadilan ataupun jalur perdamaian di luar pengadilan.

Dalam kenyataannya, jika para pihak yang berperkara bukan seorang sarjana hukum atau ahli hukum maka dalam hal beracara di muka Pengadilan ia akan mengalami kesulitan baik dalam membuat surat gugatan, replik, duplik, membuat memori banding, atau kasasi, untuk mempertahankan hak dan kepentingannya, dan surat gugatan yang diajukan itupun mungkin tidak dapat diterima ataupun ditolak oleh hakim di Pengadilan maka mereka kemudian bergantung kepada profesi advokat guna menyelesaikan segala permasalahan hukum yang dihadapinya. Kondisi ini menempatkan profesi advokad pada profesi penting dalam kehidupan masyarakat. Advokat sebagai wakil atau kuasa hukum dalam perkara perdata di muka hakim atau Pengadilan dan kesulitan dari klien dapat diatasi. Berdasarkan hal itu maka dapat diberikan satu alasan bahwa sebenarnya cukup besar kebutuhan akan kuasa bagi pihak yang berperkara karena pada umumnya mereka tidak tahu bagaimana memperoleh hak-hak dan kewajibannya di dalam bidang hukum. Perwakilan atau pemberian kuasa diatur dalam Pasal 123 HIR (Herziene Indonesische reglement) dan pasal 147 R.Bg (Reglement voor de buitengewesten).

Menurut ketentuan Undang-Undang pihak yang berperkara dapat menguasakan perkaranya kepada orang lain dengan surat kuasa khusus atau bijzondere scitelijke machtiging atau specially write authorization. Memang baik HIR maypun R.Bg tidak mewajibkan para pihak yang berperkara untuk menunjuk seorang atau beberapa orang Advokat untuk mewakilinya hadir menangani perkaranya di Pengadilan. Sehingga sepenuhnya memberikan kebebasan bagi para pihak mau menunjuk advokat atau tidak dalam berperkara di muka pengadilan. Advokat sebagai profesi hukum dikenal dengan istilah advocaat dan procureur di Negeri Belanda, Sedangkan pengertian Advokat menurut Undang-Undang No 18 
Tahun 2003 Tentang Advokat Pasal 1 ayat l, Advokat adalah orang yang berprofesi memberikan jasa hukum baik di dalam maupun di luar Pengadilan yang memenuhi persyaratan berdasarkan ketentuan Undang-undang Advokat.

Pasal 1 ayat 2 Undang-Undang Nomor 18 Tahun 2003 tentang Advokat menjelaskan tentang definisi jasa hukum, jasa hukum adalah "Jasa yang di berikan Advokat berupa memberikan konsultasi hukum, bantuan hukum, menjalankan kuasa, mewakili, rnendampingi, membela dan melakukan tindakan hukum lain yang untuk kepentingan hukum klien". Selanjutnya Pasal 1 ayat 3 Undang- Undang Nomor 18 Tahun 2003 tentang Advokat menyatakan tentang definisi klien, klien adalah Orang, badan hukum atau lembaga lain yang menerima jasa hukum dari advokat.

Advokat berstatus sebagai penegak hukum seperti yang tertera pada Pasal 5 ayat (1) Undang- Undang Nomor 18 tahun 2003. Kata penegak hukum (Law enforcer) selama ini setalu dikaitkan dengan mereka yang mempunyai untuk melakukan pemaksaan. Dalam hal ini tentu saja advokat tidak mempunyai wewenang sehingga perlu diamati bagaimana sebenarnya profesi advokat. Profesi advokat lebih merupakan profesi (beroef). Advokat juga merupakan profesi mementingkan kepentingan klien dari pada kepentingan materi.

Dalam upaya menjunjung tinggi citra profesi advokat sebagai profesi yang terhormat, profesi Advokat bukan hanya sekedar mencari pendapatan semata, tetapi juga harus memperjuangkan nilai kebenaran dan keadilan karena di dalamnya terdapat idealisme dan moralitas. Dengan hal ini perlu diperhatikan pendapat dari Immanuel Kant "Dalam hukum, seorang bersalah kalau ia melanggar hak orang lain". Dalam etika, orang bersalah kalau dia berfikir untuk melakukan sesuatu yang tidak boleh.

Advokat diharapkan dapat memperlancar proses persidangan dengan ilmu pengetahuan hukum dan keterampilan yang dimiliki untuk berargumentasi dengan pihak lawan dalam usaha mempertahankan, melindungi hak dan kepentingan klien.

Profesi advokat lahir dari masyarakat untuk masyarakat yang di dorong oleh hati nuraninya untuk berkiprah menegakkan hukum dan keadilan serta mewujudkan supremasi hukum dalam semua aspek kehidupan.

Profesi advokat adalah profesi yang mulia dan terhormat (offium nobile), menjalankan tugas pekerjaan menegakkan hukum di pengadilan bersama jaksa dan Dalam peradilan perdata, Advokat/Pengacara berkedudukan sebagai kuasa atau wakil kliennya. Landasan hukum advokat dalam peradilan perdata adalah Pasal 123 
HIR (Herziene Indonesisch Reglement)/ 147 R.Bg dimana dalam Pasal 123 HIR / 147 R.Bg ayat (1):

" Bilamana dikehendaki, kedua belah pihak dapat dibantu atau diwakili oleh kuasa yang dikuasakannya untuk melakukan itu dengan surat kuasa teristimewa, kecuali kalau yang memberi kuasa itu dalam surat permintaaan yang ditanda tanganinya dan dimasukkan menurut ayat pertama Pasal 118 atau jika gugatan dilakukan dengan lisan menurut Pasal 120, maka dalam hal terakhir ini, yang demikian itu harus disebutkan dalam catatan yang dibuat dengan surat gugat ini."

Oleh karenanya Pasal 123 HIR/147 R.Bg ini, hukum acara perdata mengenal adanya sistem lembaga perwakilan. Sehingga peran Advokat/Pengacara dapat membantu pihak-pihak yang berpekara dalam mempertahankan hukum perdata materiil. Hukum perdata bagi seorang Advokat adalah seorang interprestasi dan perang ilmiah, karena itu sebagai Advokat wajib mempertahankan unsurunsurnya di dalam hukum acara perdata.

Dasar adanya sistem lembaga perwakilan adalah dikarenakan masih banyaknya pencari keadilan yang kurang mampu atau kurang memahami dalam mengajukan gugatan dan tangkisan dengan rumusan sedemikian rupa. Oleh karena itu, lembaga perwakilan bermaksud menjaga agar jangan sampai pihak-pihak pencari keadilan dirugikan hanya membuat kesalahan-kesalahan elementer dalam hukum acara perdata yang terikat oleh banyaknya peraturan dan macam-macam formalitas.

Oleh karena itu, sebagai advokat yang bertindak untuk dan atas nama kliennya diharuskan memiliki kemampuan dan keberanian berpekara, apalagi mengingat kliennya telah memberikan kepercayaan yang besar padanya.

\section{B. RUMUSAN MASALAH}

Berdasarkan latar belakang masalah yang telah diuraikan di atas, maka penulis membatasi perumusan masalah sebagai berikut:

1. Bagaimana peran dan fungsi advokat dalam penyelesaian perkara perdata?

2. Apakah hambatan-hambatan yang dialami advokat dalam memberikan jasa hukum dan solusinya dalam perkara perdata?. 


\section{MEDOTE PENELITIAN}

Tipe Penelitian

Penelitian ini adalah penelitian hukum Normatif. Pendekatan yang digunakan antara lain pendekatan peraturan perundang- undangan dan pendekatan teori- teori hukum.

\section{TUJUAN PENELITIAN:}

1. Untuk mengetahui bagaimanakah menggambarkan dan memberikan penjelasan tentang peran dan fungsi advokat dalam hal perkara perdata.

2. Bagaimana upaya untuk mengetahui hambatan-hambatan yang ditemui advokat dalam penyelesaian perkara perdata dan apa solusinya.

\section{E. Manfaat Penelitian adalah:}

1. Manfaat Teoritis : Agar dapat diperoleh suatu pemahaman yang tepat mengenai peran dan fungsi advokat dalam perkara perdata.

2. Manfaat Praktis : Diharapkan dapat menjadi suatu sumbangan pemikiran bagi calon-calon sarjana hukum yang akan menjadi penegak hukum, agar dapat menegakkan kebenaran dan keadilan sesuai dengan peraturan perundang-undangan yang berlaku.

\section{F. TINJAUAN PUSTAKA}

\section{Istilah dan Pengertian}

Untuk memahami apa itu yang dimaksud Lawyer, maka kita perlu mengenal istilah-istilah yang sudah ada dan definisinya. Bila sudah mengenal istilah-istilah, mengetahui definisi-definisi, maka akan sangat mudah untuk memahami pengertian Lawyer.

Dalam Bahasa Indonesia. Lawyer diterjemahkan menjadi "pengacara". Kadang juga disebut "Advokat”, “Ajuster”, “Pembela”, “Penasehat Hukum”, “Prokol”. Dari sekian banyak istilah itu yang paling sering kita dengar adalah "Advokat", "Pengacara", "Pembela”, "Penasehat Hukum".1

Dewasa ini dengan kemajuan elektronik dan media cetak istilah-istilah tersebut semakin akrab serta wajah-wajah Lawyer pun makin tak asing, semisal

1 Ari Yusuf Amir, Strategi Bisnis Jasa Advokat, (Yogyakarta:Navila Idea,2010), h.16. 
acara televisi ILC (Indonesia Lawyer Club) di tvOne, yang acaranya megupas kasuskasus hukum yang sedang bomming.

Istilah dan pengertian Advokat dan Pengacara sebagai nama profesi Hukum dalam sejarahnya telah dikenal dengan istilah Advokat dan Procureur di Negara Belanda, dan istilah Barrister dan Solicitoir di Inggris, Advocate di Singapura, istilah Lawyer di Amerika yang sekarang menjadi istilah yang digunakan secara internasional. ${ }^{2}$ Istilah Penasehat Hukum atau Profesi Hukum adalah istilah resmi di Indonesia, yang mengaburkan pengertian Advokat sebagai profesi hukum, Maksudnya Legal Profession atau Profesi Hukum itu adalah Lawyer atau Advokat dan bukan Penasehat Hukum atau Konsultan Hukum. ${ }^{3}$ Jadi pekerjaan yang dilakukan oleh Advokat itu sudah mencangkup Penasehat Hukum atau Konsultan Hukum.

Sebenarnya kesemua istilah mempunyai makna yang sama karena istilah tersebut hanyalah persoalan penyebutan yang bertemu dalam satu bidang yang sama yakni profesi yang menyediakan jasa hukum. Didalam (Undang - Undang Nomor 18 tahun 2003 tentang Advokat,4 Pasal 1,2\&4) Advokad adalah orang yang berprofesi memberi Jasa Hukum, baik di dalam maupun di luar Pengadilan yang memenuhi persyaratan berdasarkan Undang-Undang. Jasa Hukum adalah jasa yang di berikan advokad berupa memberikan konsultasi, menjalankan kuasa, mewakili mendampingi, membela dan melakikan tindakan hukum lain untuk kepentingan Hukum klien.

Klien adalah orang, atau Badan Hukum, atau Lembaga lain yang menerima jasa hukum dari advokat. Secara umum, tujuan lawyer adalah untuk membantu kliennya dalam memperoleh hak-haknya dalam proses penegakan hukum, baik melalui jalur Pengadilan (litigation) maupun di luar jalur Pengadilan (non litigation). Penggunaan jasa bantuan hukum melalui para Lawyer sangat tergantung kepada kebutuhan kliennya, jenis kasus apa yang diperselisihkan dan tujuan hukumnya. ${ }^{5}$ Maksudnya jenis apa yang diperselisihkan serta tujuan hukumya.

Untuk menjadi seorang Lawyer ada syarat syarat umum yang di atur oleh Undang-Undang No. 18 Tahun 2003 tentang Advokat, adapun syarat khususnya

2 Ropaun Rambe, TehnikPraktik Advokat, (Jakarta: PT Grasido, 2001) , h. 6

${ }^{3}$ Ibid.,hal.7

${ }^{4}$ Otto Hasibuan , Kitab Advokat Indonesia, (Jakarta, Peradi, 2007),h.42

5 Didi Kusnadi, Bamtuan Hukum Dalam Hukum Islam, (Jakarta:

Kementrian Agama RI, 2011), h. 67 
adalah berlatar belakang pendidikan tinggi hukum maksudnya lulusan Fakultas Hukum, Fakultas Syariah, Perguruan Tinggi Hukum Militer, Perguruan Tinggi Ilmu Kepolisian. Lulusan sarjana tidak cukup untuk menjadi seorang Lawyer, namun harus melalui pendidikan khusus profesi advokat (PKPA) terlebih dahulu yang di selenggarakan oleh Organisasi Advokat. ${ }^{6}$ Setelah PKPA tidak lantas seorang calon lawyer berjalan mulus begitu saja menjadi Lawyer karena memjadi lawyer tidak mudah seperti membalik tangan, dan selanjutnya harus mengikuti ujian profesi Advokat hingga memperoleh sertifikat kelulusan dari organisasi Avokat. Setelah lulus juga tidak serta merta langsung bisa praktik di pengadilan di seluruh Indonesia karena dalam Pasal 3 Ayat (1) huruf g UU Advokat di jelaskan harus magan terlebih dahu di kantor advokat dan harus dilakukan secara kontinyu sekurangkurangnya selama dua tahun.

Setelah kira-kira sudah mempunyai persyaratan yang cukup sesuai UndangUndang yang berlaku maka selanjutnya bisa diangkat oleh Organisasi Advokat dan di buatkan salinan keputusan pengangkatan Advokat yang nantinya di asampaikan kepada MA dan Menteri, setelah itu harus disumpah jabatan di Pengadilan Tinggi setempat berdasarkan Pasal 4 Ayat (1) UU No 18 tahun 2003. Saat mengucap sumpah harus memakai toga, sesuai Keputusan Menteri Kehakiman Republik Indonesia No; M. 07. UM.01.06.Tahun 1983. Setelah sumpah dilaksanakan maka salinan berita acaran sumpah diserahkan kepada panitera Pengadilan Tinggi yang bersangkautan dikirim ke Mahkamah Agung, Menteri, dan Organisasi Advokat untuk arsip Negara. ${ }^{7}$

Setelah selesai pengangkatan, Advokat wajib menjadi anggota Organisasi advokat semisal PERADI. IKADIN, SPI, AAI, APSI, AKHI, HKHPI, HAPI. Setelah menjadi anggota maka ia sudah mempunyai hak dan kewajiban melaksanakan profesi sebagai Lawyer. Apabila seorang Lawyer telah menerima kuasa dari klien dalam suatu urusan perdata dalam bentuk sengketa kewarisan, maka ia sudah mempunyai sebuah kewajiban mewakili klienya dalam mengurus masalah yang dihadapi, bentuknya memperjuangkannya sampai selesai, hal pertama Lawyer harus mengetahui seluk-beluk masalah yang dihadapi klien. Ibaratnya dokter dengan pasienya, lawyer mempunyai hak penuh dalam hal memperoleh informasi dari klien.

6 Sartono dan Bhakti Suryani, Prinsip-Prisip Dasar Profesi Advokad, (Jakarta: dunia cerdas, 2013), h.10

${ }^{7}$ Ibid, h. 22-23 


\section{Kedudukan Advokat}

Asas kebebasan Advokat atau "Independence of Lawyers" merupakan syarat mutlak dari profesi yang diakui dan diterima serta dipertahankan dalam Konferensi-Konferensi Advokat di seluruh Dunia. Dan disyaratkan dalam resolusi Kongres VII PBB Tahun 1985 yang menyatakan bahwa asas kebebasan Advokat atau Independence of Lawyers merupakan syarat mutlak sebagai Komplement atau bagian yang tidak terpisah dari kebebasan peradilan atau sebagai "Complement of the independence of the judiciary" ${ }^{8}$

Pada dasarnya Advokat merupakan profesi yang bebas; dalam artian tidak ada batas kewenangan dalam melakukan bantuan, pembelaan, perwakilan atau pendampingan terhadap klienya. Maka tugasnya sebagai kewajiban profesinya, sebagaimana diamanatkan oleh Undang-Undang, demikian juga Advokat bebas melakukan tugasnya, baik yang berkaitan dengan kewenangan materi hukum atau wilayah praktek di lembaga peradilan manapun. ${ }^{9}$ dan bisa berpraktek diseluruh wilayah peradilan diseluruh Wilayah Negara Indonesia.

Sebagai Lawyer memang memiliki kebebasan dan kemandirian yang di jamin oleh Hukum dan peraturan perundang-undangan (Pasal 5 UU Advokat). ${ }^{10}$ Akan tetapi tidak sepenuhnya memiliki kekebalan (imunity) absolut. Pada Pasal 6 hingga Pasal 13 UU Advokat jelas-jelas ada ketentuan yang dapat menjerat seorang yang memberikan jasa hukum sebagai Advokat/Lawyer. Seorang Lawyer akan hilang imunitasnya jika melakukan hal-hal sebagai berikut:

a. Mengabaikan atau menelantarkan kepentingan klienya.

b. Berbuat atau bertingkah laku, bertutur kata, atau mengeluarkan perkataan atau menunjukkan sikap tidak hormat terhadap Hukum, peraturan perundang undangan atau Pengadilan.

c. Berbuat dengan hal yang bertentangan dengan kewajiban, kehormatan dan martabat profesi.

d. Melakukan pelanggaran terhadap peraturan perundang undangan atau melakukan perbuatan tercela.

e. Melanggar sumpah atau janji Advokat dan atau kode etik profesi Advokat.

8 Ropaun Rambe, Tehnik Praktik Advokat, (Jakarta: PT Grasido, 2003) , h.38

${ }_{9}^{9}$ Rosadi dan Hartini, Advokat Dalam Prespektif Islam, (Jakarta: Ghalia Indonesia).

10 Bambang Kesowo, Undang-Undang Advokat No. 18 Tahun 2003, (Bandung: Citra Umbara,2003), h. 8. 
Ketentuan Pidana UU Advokat Pasal 31 menegaskan bahwa setiap orang yang sengaja menjalankan profesi Advokat dan bertidak seolah-olah sebagai Advokat, tetapi bukan Advokat sebagai mana yang diatur dalam Undang-Undang ini, dipidana dengan pidana kurungan penjara paling lama 5(lima) Tahun, dan denda paling banyak Rp. 50.000.000,00 (lima puluh juta rupiah).

Advokat, Penasehat Hukum, Pengacara Praktik, dan Konsultan Hukum dinyatakan sebagai Advokat, dan salah satu syarat menjadi Advokat adalah bukan Pegawai Negeri atau Pejabat Negara adapun yang di maksud Pegawai Negeri adalah Pegawai NegeriSipil, Anggota TNI, Anggota Polisi. Sedang yang dimaksud Pejabat Negara adalah anggota MPR, anggota Lembaga Negara Lain, Menteri, Duta Besar, Gubernur, Walikota, Bupati, dan anggota DPR.

Seorang Advokat dapat beracara dimanapun diseluruh Nusantara, di semua Lingkungan Peradilan, misalnya di Lingkungan Peradilan Umum, Peradilan Agama, Peradilan Militer, dan PeradilanTata Usaha Negara (lihat SEMA No.8 Tahun 1987). Kedudukan Advokat pada salah satu Pengadilan Tinggi sebagaimana disebutkan dalam Surat Keputusan Menteri Kehakiman RI hanya untuk kepentingan pengawasan dan bukan sebagai pembatasan Wilayah kerjanya sebagai Advokat atau Pengacara.

Kartu Advokat yang diterbitkan Pengadilan Tinggi ia terdaftar, sifatnya hanya tindakan administratif sebagai kartu identitas. Apabila kartu anggota itu masa berlakunya berakhir tidak berarti kedudukan sebagai Advokat atau Pengacara selesai. Dengan menunjukkan foto copy SK Menteri Kehakiman RI, Advokat dapat beracara dimuka pengadilan. Bagi Advokat yang mengadakan praktek di luar Wilayah Hukum Pengadilan Tinggi di mana ia terdaftar dan berkedudukan, ia cukup mengirim surat pemberitahuan kepada Pengadilan Tinggi dimana ia terdaftar dengan tembusanya kepada Ketua Mahkamah Agung RI, Ketua Pengadilan Tinggi (PTA kalau Pengadilan Agama), dan kepada Ketua Pengadilan Negeri (PA kalau Lingkungan Pengadilan Agama) dimana ia hendak mengadakan praktek beracara. ${ }^{11}$

Advokat dalam hal kedudukan sebagai penegak hukum dengan tujuan memperjuangkan keadilan adalah setara dengan (Hakim, jaksa, polisi) karena peranya sama-sama pentingnya semisal Polisi dengan penyidikanya, Jaksa dengan tuntutanya, Hakim dengan putusanya, sedangkan Lawyer dengan pembelaanya. Namun dalam peran dan fungsinya masing masing berbeda. Ditinjau dari wilayah

11 H. Abdul Manan, Penerapan Hukum Acara Perdata di Lingkungan Peradilan Agama, (Jakarta: Yayasan al Hikmah 2000), h.45 
kekuasaanya, Hakim menjalankan kekuasaan secara yudikatif, jaksa dan polisi secara eksekutif sedangkan Lawyer menjalankan atas kuasa dari Klienya dan tidak terpengaruh oleh kekuasaan Negara (eksekutif dan yudikatif).

\section{Tugas dan Fungsi Advokat}

\section{a. Tugas Advokat}

Tugas adalah kewajiban; sesuatu yang wajib dilakukan atau ditentukan untuk dilakukan. Tugas Advokat berarti sesuatu yang wajib dilakukan oleh Advokat dalam memberikan Jasa Hukum kepada masyarakat/klienya. Oleh karena itu, Advokat dalam menjalankan tugasnya bertanggung jawab kepada Negara, masyarakat, Pengadilan, klien,dan pihak lawanya. ${ }^{12}$ Lawyer dalam menjalankan tugasnya itu tidak terinci dalam uraian tugas karena bukan merupakan pejabat Negara.

Tanggung jawab kepada masyarakat itu tercermin pada Pasal 3 dan 4 Kode Etik Advokat Tahun 2002, dalam pemberian bantuan Hukum secara Cuma-Cuma, seorang Lawyer di jelaskan dalam hal tersebut tidak boleh menolak, ataupun mengesampingkan orang yang meminta bantuan dan menanganinya tidak seperti klien yang memberi imbalan.

Dalam hal tanggung jawab kepada pengadilan, seorang Lawyer tidak diperbolehkan berlaku curang terhadap (majlis) Hakim dan Advokat lawan. Lawyer mempunyai dua kewajiban yaitu pertama, dia berkewajiban untuk setia (loyal) kepada klienya. Kedua, berkewajiban mempunyai iktikad baik dan terhormat dalam hubungan dengan pengadilan. Sebagaimana diatur dalam Kode Etiknya dalam poin mengenai cara bertindak menangani perkara. ${ }^{13}$

Dalam melakukan pembelaan kepada kepentingan kliennya bisa bersifat konsultasi (posisi sebagai konsultan) yang dilakukan di luar maupun di dalam Pengadilan. untuk membela kepentingan kliennya sebagai guide procedur maksudnya Lawyer tidak hanya bermodal gagah serta tampan, atau waton ngeyel namun haruslah bersikap ilmiyah, obyektif, jujur, dan berfikir logis. Karena Lawyer merupakan rechtsvinding yakni selaku salah satu unsur penemu Hukum yang

12 Rahmat Rosadi dan Sri Hartini, Advokat dalam Perspektif Islam dan Hukum Positif, (Jakarta: Galia Indonesia,2003), h.84

13 Sartono dan bhakti suryani, Prinsip-Prisip Dasar Profesi Advokad, (Jakarta: dunia cerdas, 2013), h,.93 
merupakan komponen penentu dalam rangka membantu Hakim dalam menemukan hukum.

Sebagai Konsultan Hukum dari masyarakat. dalam setiap persoalan Hukum yang memintakan penjelanya atau nasehatnya. Seorang Lawyer sangat tidak di benarkan oleh Kode Etiknya untuk memberikan nasehat-nasehat yang menyesatkan atau mendorong orang untuk berbuat yang bertentangan dengan norma-norma kemasyarakatan. mengabdi kepada Hukum, dalam hal ini seorang Lawyer harus bisa memberikan kontribusinya secara nyata terhadap pembangunan Hukum di Negeri ini.14. Kontribusinya bisa berupa pikiran-pikiran pribadinya melalui tulisan atau karya ilmiyah atau berupa sumbangan pemikiran secara organisatoris, berupa seminar, diskusi atau semacamnya. Atau bisa pula dalam bentuk ikut merumuskan RUU yang akan berlaku.

Pada dasarnya tugas pokok seorang advokat dapat dirinci sebagai berikut:

1. Memperjuangkan tegaknya kebenaran keadilan hukum dan hak-hak asasi manusia.

2. Menghayati bahwa profesi advokat adalah mempunyai martabat yang tinggi, mulia dan dihormati.

3. Menaati kode etik advokat.

4. Membela dan melindungi klien pencari keadilan.

5. Meningkatkan pengetahuannya terutama dalam bidang ilmu hukum, perundang-undangan, peraturan-peraturan pemerintah serta perkembangan ilmu sosial lainnya yang berkaitan dengan ilmu hukum.

6. Meningkatkan pembinaan budi pekerti dan budaya sebagai tuntunan pembinaan manusia Indonesia seutuhnya.

7. Melaksanakan tugas pekerjaan profesi dengan segala kejujuran, kesungguhan, kebijaksanaan, keberanian, agar kepentingan yang dipercayakannya dapat terwujud dengan baik dan penuh rasa tanggung jawab.

8. Memberikan bantuan hukum kepada masyarakat pencari keadilan tanpa memandang agama, kepercayaan, aliran politik, keturunan, kewarganegaraan, kedudukan sosial baik kaya maupun miskin.

9. Memberikan bantuan hukum secara cuma-Cuma.

14 Jeremias Lemek, Mencari Keadilan, (Jakarta: Galang, 2007), h. 42-44 
10. Menghormati kepada pengadilan selaku officer of the court dan membantu hakim dalam mencari kebenaran guna mencapai keputusan yang adil.

11. Pertentangan perdebatan di muka sidang pengadilan dalam membela perkara, tidak menjadikan permusuhan pribadi.

Seorang advokat Indonesia harus mampu memiliki kesadaran untuk memberikan nasehat dan bantuan hukum kepada setiap orang yang memerlukannya secara nondiskriminatif tanpa melihat perbedaan agama, kepercayaan, suku, keturunan, keyakinan politik, atau kedudukan sosialnya. Ia merupakan etika normatif yang menjadi kewajiban bagi advokat Indonesia, bahwa ia harus bersedia memberi nasehat dan bantuan hukum yang diminta kepadanya.

\section{b. Fungsi Advokat}

Fungsi dan Peran Lawyer dalam menjalankan perannya di dalam maupun di luar Pengadilan sebagai berikut: ${ }^{15}$ sebagai pengawal Konstitusi, memperjuangkan HAM di Negara Hukum Indonesia, melaksanakan kode etiknya sebagai Advokat, memegang teguh sumpah jabatan dalam menegakkan Hukum keadilan dan kebenaran, menjunjung tinggi serta mengutamakan idealisme (nilai keadilan dan kebenaran), menjunjung tinggi citra profesi Advokat yang terhormat (officium nobile), melindungi dan memelihara kemendirian, kebebasan, derajat dan martabat Advokat, meningkatkan mutu pelayanan terhadap masyarakat, menangani perkara sesuai Kode Etik Advokat, membela klien dengan cara jujur dan bertanggung jawab, mencegah penyalah gunaan keahlian, memelihara kepribadian Advokat, menjaga hubungan baik dengan klien dan teman sejawat, memelihara persatuan dan kesatuan Organisasi Advokat.

Dalam menjalankan tugasnya seorang Advokat harus berfungsi:

a. Sebagai pengawal Konstitusi dan hak azasi manusia.

b. Memperjuangkan hak-hak azasi manusia dalam negara hukum Indonesia

c. Melaksanakan kode etik advokat

d. Memegang teguh sumpah advokat dalam rangka menegakkan hukum, keadilan dan kebenaran.

e. Menjungjung tinggi serta mengutamakan idealisme (nilai keadilan dan kebenaran) dan moralitas.

15 Ropuan Rambe, Op.cit, h. 28-29 
f. Menjungjung tinggi citra profesi advokat sebagai profesi terhormat (officium nobile)

g. Melindungi dan memelihara kemandirian, kebebasan, derajat, dan martabat advokat.

h. Menjaga dan meningkatkan mutu pelayanan advokat terhadap masyarakat. i. Menangani perkara-perkara sesuai kode etik advokat.

i. Membela klien dengan cara yang jujur dan bertanggung jawab.

j. Mencegah penyalahgunaan keahlian dan pengetahuan yang merugikan masyarakat.

k. Memelihara kepribadian advokat.

l. Menjaga hubungan baik dengan klien maupun dengan teman antara sesama advokat yang didasarkan pada kejujuran, kerahasiaan dan keterbukaan serta saling menghargai dan mempercayai.

m. Memelihara persatuan dan kesatuan advokat agar sesuai dengan wadah tunggal organisasi advokat.

n. Memberikan pelayanan hukum (legal service)

o. Memberikan nasehat hukum (legal advice)

p. Memberikan konsultasi hukum (legal consultation)

q. Memberikan pendapat hukum (legal opinion)

r. Menyusun kontrak-kontrak (legal drafting)

s. Memberikan informasi hukum (legal information)

t. Membela kepentingan klien (litigation)

u. Mewakili klien di muka pengadilan (legal representation)

v. Memberikan bantuan hukum dengan Cuma-Cuma kepada rakyat yang lemah dan tidak mampu ( legal aid).16

\section{G. PEMBAHASAN}

\section{Peranan Advokat dalam Memberikan Jasa Hukum dalam Perkara Perdata.}

Pada prinsipnya memakai jasa advokat dan tidak seluruh perkara tersebut sampai ke persidangan dikarenakan dalam berperkara yang menjadi tujuan utama adalah perdamaian, baik perdamaian tersebut terjadi sebelum sidang atau sidang sedang berjalan. Advokat sangat berperan penting dalam berperkara dan beracara di muka Pengadilan dikarenakan advokat dibekali pengetahuan dan keahlian dibidang hukum serta dapat dilihat bahwa pelaksanaan peranan advokat

\footnotetext{
${ }^{16}$ Ibid
} 
dalam memberi jasa hukum kepada klien khususnya dalam perkara perdata adalah menyangkut perkara yang dibelanya dengan tujuan untuk membela kepentingan kliennya. Selain itu advokat juga berkewajiban untuk memberikan perhatian yang penuh terhadap setiap perkara yang ditanganinya dan disamping itu kehadiran advokat sangat membantu mulai dari pendaftaran perkara selama proses persidangan sampai pada saat pembacaan putusan oleh hakim, tidak dapat dipungkiri kehadiran advokat itu juga dapat memperlambat proses persidangan seperti pembacaan, jawaban tergugat, replik, duplik dan get rekopensi dibuat secara tertulis.

Peranan advokat adalah dalam memberikan jasa hukum tidak hanya sebatas satu tingkat saja tetapi dapat dilaksanankan mulai dari tingkat Pengadilan Negeri, Pengadilan Tinggi, maupun sampai ketingkat Mahkamah Agung. Pelaksanaan peranan advokat dalam memberikan jasa hukum pada klien tergantung dari surat kuasa sejauh mna kuasa diberikan.

Di dalam menjalankan profesinya sebagai seorang Advokat mempunyai tugas, hak dan tanggungjawabnya, ini dapat di lihat dalam Pasal 14 s/d 20 Undang-Undang Nomor 18 Tahun 2003.

Tugas Advokat adalah sebagai berikut:

a. Memberi konsultasi hukum

b. Memberi bantuan hukum

c. Menjalankan kuasa

d. Mewakili

e. Mendampingi

f. Membela dan melakukan tindakan hukum lain untuk kepentingan klien.

Hak dan Tanggungjawab Advokat adalah sebagai berikut:

a. Bebas mengeluarkan pendapat atau pernyataan

b. Membela perkara.

c. Memperoleh informasi, data, dan dokumen lainnya.

d. Dan berhak mendapat honorarium. 
Pada dasarnya, Kode Etik Advokat dan Undang-Undang Advokat mengatur tentang hubungan Advokat dengan Klien dan Hubungan Advokat dengan teman sejawat. Hubungan antara Advokat dengan klien diatur di dalam Pasal 4 Kode Etik Advokat, yaitu:

a) Advokat dalam perkara-perkara perdata harus mengutamakan penyelesaian dengan jalan damai.

b) Advokat tidak dibenarkan memberikan keterangan yang dapat menyesatkan klien mengenai perkara yang sedang diurusnya.

c) Advokat tidak dibenarkan menjamin kepada kliennya bahwa perkara yang ditanganinya akan menang.

d) Dalam menentukan besarnya honorarium Advokat wajib mempertimbangkan kemampuan klien.

e) e. Advokat tidak dibenarkan membebani klien dengan biaya- biaya yang tidak perlu.

f) Advokat dalam mengurus perkara cuma-cuma harus memberikan perhatian yang sama seperti terhadap perkara untuk mana ia menerima uang jasa.

g) Advokat harus menolak mengurus perkara yang menurut keyakinannya tidak ada dasar hukumnya.

h) Advokat wajib memegang rahasia jabatan tentang hal-hal yang diberitahukan oleh klien secara kepercayaan dan wajib tetap menjaga rahasia itu setelah berakhirnya hubungan antara advokat dan klien itu.

i) Advokat tidak dibenarkan melepaskan tugas yang dibebankan kepadanya pada saat yang tidak menguntungkan posisi klien atau pada saat tugas itu akan dapat menimbulkan kerugian yang tidak dapat diperbaiki lagi bagi klien yang bersangkutan, dengan tidak mengurangi ketentuan sebagaimana dimaksud dalam Pasal 3 huruf (a).

j) Advokat mengurus kepentingan bersama dari dua pihak atau lebih harus mengundurkan diri sepenuhnya dari pengurusan kepentingankepentingan tersebut, apabila dikemudian hari timbul pertentangan kepentingan antara pihak-pihak yang bersangkutan.

k) Hak retensi (penyimpanan/penahanan) Advokat terhadap klien diakui sepanjang tidak akan menimbulkan kerugian kepentingan klien. 
Hubungan antara Advokat dengan klien sangat erat kaitannya dengan pekerjaan utama Advokat sebagai profesi seperti:

a. Pemberian nasihat hukum kepada masyarakat yang memerlukannya.

b. Pembelaan kepentingan masyarakat.

c. Membuat draf kontrak (perjanjian) bagi kepentingan para pihak yang berminat untuk mengadakan hubungan dagang atau hubungan kerja.

d. Memfasilitasi kepentingan masyarakat yang menjadi kliennya dalam suatu proses perundingan guna menyelesaikan perselisihan hukum, dan lain-lain bentuk pelayanan hukum yang diperlukan dunia usaha.

Syarat-syarat Advokat Menurut Undang-undang No.18 Tahun 2003 tentang advokat secara jelas mengemukakan syarat-syarat untuk dapat diangkat sebagai advokat. Hal itu dijelaskan dalam pasal 2 ayat (1) yang memberikan persyaratan umum bahwa "yang dapat diangkat sebagai advokat adalah sarjana yang berlatar belakang pendidikan tinggi hukum dan setelah mengikuti pendidikan khusus advokat yang dilaksanakan organisasi". Selanjutnya persyaratan umum yang diuraikan pasal 2 ayat (1) tersebut dijabarkan secara lebih rinci dalam pasal 3 ayat (1) yang menyatakan bahwa "untuk dapat diangkat menjadi advokat harus memenuhi persyaratan sebagai berikut:

a. Warga negara Republik Indonesia;

b. Bertempat tinggal di Indonesia;

c. Tidak berstatus sebagai Pegawai Negeri atau pejabat negara;

d. Berusia sekurang-kurangnya 25 (dua puluh lima) tahun;

e. Berijasah sarjana yang berlatar belakang pendidikan tinggi hukum sebagaimana dimaksud dalam pasal 2 ayat (1);

f. Lulus ujian yang diadakan oleh organisasi advokat;

g. Magang sekurang-kurangnya 2(dua) tahun terus menerus pada kantor advokat;

h. Tidak pernah dipidana karena melakukan tindak pidana kejahatan yang diancam dengan pidana penjara 5 (lima) tahun atau lebih;

i. Berperilaku baik, jujur, bertanggung jawab, adil, dan mempunyai integritas tinggi; 
Selain daripada itu, seorang advokat, pengacara, penasehat hukum harus memenuhi syarat khusus sebagai berikut:

1. Keahlian dalam hukum.

Seorang yang berprofesi sebagai pengacara, advokat, dan penasehat hukum senantiasa bergelut dengan ilmu hukum dan pengetahuan masyarakat yang berkembang, maka diperlukan seorang ahli hukum yang sarjana hukum yang berkemampuan melakukan tugas kewajiban yurist, baik berupa teori maupun praktek yang diterapkan sesuai dengan perkembangan sosial dalam lingkungannya secara obyektif dan rasional guna menemukan keadilan hukum dan kebenaran hukum.

2. Kebebasan profesi

Yang dimaksud kebebasan profesi adalah tidak terikat pada suatu organisasi atasan atau organisasi induk, tidak mempunyai hubungan jenjang kedinasan atau hierchis atasan yang bekerja dengan bebas, tidak terikat oleh siapapun dalam menjalankan suatu perkara, namun dengan demikian tidak berarti meninggalkan rasa solidaritas terhadap rekan se profesi maupun instansi yang terkait. Kebebasan profesinya merupakan kebebasan oleh rasa tanggung jawab atas dasar landasan hukum pancasila dan UUD 1945.

3. Pengabdian kepada kepentingan umum

Bersedia membantu dan menolong orang-orang yang berada dalam kesulitan karena mempunyai suatu permasalahan memberikan bantuan jasa-jasa hukum kepada siapapun juga yang memerlukannya, guna terhindar dari permasalahan yang dihadapi oleh pencari keadilan. Tentu dengan batas-batas keyakinan dengan bahwa yang akan dibela tidak menjadi korban ketidakadilan. Kepentingan umum lebih diutamakan daripada kepentingan pribadinya. 
4. Profesinya tidak untuk mencari kekayaan

Seorang advokat adalah bukan pegawai negeri, bukan pegawai swasta suatu instansi. Akan tetapi merupakan pekerjaan swasta. Jadi honorarium bebas jasa yang diperolehnya berasal dari kliennya dan insidentil serta tidak boleh menerima honorarimu lain dalam perkara lain yang bertentangan dengan perkara yang sedang dibela dan tidak boleh menarik honorarium dan keuntungan yang berlipat ganda.

5. Hubungan kepercayaan dengan klien

Kredibilitas merupakan pertaruhan dalam profesinya, sampai sejauhmana ia dapat menyimpan rahasia kliennya yang dipercayakan kepadanya. Dalam memberikan bantuan kepada kliennya, maka sebelum bertindak harus mendapatkan data-data selengkapnya yang menyangkut permasalahan, bagaimana hubungan kausalitas fakta, delicti dengan fakta yurist yang menyangkut permasalahan kasus yang ada. Dalam memberikan bantuan hukum kepada klien wajib berusaha sekuat tenaga dan pikiran dengan sungguh, baik dalam usaha perdamaian maupun dalam berperkara kasus perdata dan pidana, di dalam dan di luar sidang pengadilan. Dengan demikian akan menimbulkan kepercayaan penuh oleh klien.

6. Merahasiakan kepribadian klien yang dibela

Dengan adanya saling kepercayaan yang dibela dengan pengacara yang membela, karena segala rahasia pribadi klien merupakan rahasia jabatan yang wajib dipegang teguh dalam menjalankan profesinya

7. Hak imunitas profesi

Hak imunitas yaitu hak kekebalan dalam artian suatu hak yang tidak tunduk kepada hukum yang berlaku, hak yang tidak dapat diganggu gugat oleh siapa pun. Seorang pengacara, advokat, dan penasehat hukum yang bertindak untuk kepentingan umum dan dalam melakukan pembelaan kebenaran, maka dirinya perlu mendapatkan perlindungan hukum. 
8. Kode etik

Pengertian kode etik kita batasi dalam artian tulisan atau tanda-tanda etis yang mempunyai tujuan tertentu. Mengandung norma-norma hidup yang etis, aturan tata susila, sikap, akhlak budi luhur yang pelaksanaannya diserahkan atas keinsyafan dan kesadaran dirinya sendiri. Oleh karena itu, demi menjunjung kebenaran, harkat, serta keadilan dan hati nurani advokat, perlu menjaga citra dan wibawa, harkat serta martabat dalam menjalankan praktek profesinya. Untuk itu pula perlu suatu ketentuan yang mengatur aturan main bagaimana advokat menjalankan profesinya yaitu kode etik.

\section{Hambatan-Hambatan yang dialami Advokat dalam Mencapai Tujuan Advokasi dan Cara Penyelesaiannya}

Profesi advokat profesi yang mulia dimana advokat mempunyai peranan penting dalam penegakkan hukum sesuai dengan fungsinya sebagai penegak hukum dalam menjalankan tugas mulia tersebut terkadang tidak selalu sesuai dengan apa yang diharapkan, terkadang terdapat hambata-hambatan yang berasal dari dalam maupun dari luar advokat. Berdasarkan hasil wawancara yang penulis lakukan dapat diketahui bahwa hambatan- hambatan apa saja yang dialami advokat dalam memberikan jasa hukum baik dengan klien, dari rekan seprofesi, diantaranya:

1. Hubungan dengan klien

a. Banyaknya klien yang kurang jujur dalam memberikan keterangan yang diperlukan, selain dari pada itu keterangan yang diberikan lebih cenderung kebaikan-kebaikan saja. Dengan keterangan yang baik klien berharap perkara yang dikuasakan pada advokat dapat dimenangkan pada hal yang dibutuhkan advokat adalah keterangan yang sebenarnya

tentang perkara yang dibelanya, karena akan berpengaruh pada langkah- langkah apa yang akan diambil advokat dalam memberikan membela kliennya.

b. Ketidatahuan klien dan minimnya pengetahuan klien dalam bidang hukum mengakibatkan advokat sulit untuk menjelaskan yang seharusnya diketahui oleh klien terhadap perkaranya. Kadang kala apabila klien sudah menggunakan jasa advokat sering kali menyerahkan persoalan sepenuhnya baik klien maupun eksteren perkara tersebut kepada advokat. 
c. Ketidakmampuan klien untuk menghadirkan alat bukti saksi yang mengetahui secara langsung perkara yang dipermasalahkan, hal ini dapat dilihat dalam perkara perdata berkaitan dengan ahli waris dimana perjanjian tentang objek perkara langsung pada saat ahli waris belum lahir dan orang-orang yang mengetahui langsung tentang permasalahan tersebut telah meninggal dunia. Hal inilah yang akan menyulitkan ahli waris dalam menghadirkan saksi-saksi yang mengetahui langsung tentang perkara tersebut.

d. Klien seringkali ingkar janji terhadap kewajiban honorarium yang telah disepakati. Hal tersebut sangat menyulitkan advokat dalam meberikan pelayanan jasa hukum bagi yang membutuhkan karena advokat adalah merupakan suatu lembaga swasta yang memerlukan biaya dalam pelaksanaan tugas.

2. Hubungan dengan rekan se profesi dan pihak pengadilan

Hubungan antara teman sejawat advokat haruslah dilandasi sikap saling menghormati dan saling mempercayai. Dalam melaksanakan tugasnya terkadang tidak semua sesuai dengan aturan yang telah ditetapkan terkadang terjadi hal-hal yang tidak diinginkan dalam menjalankan profesi advokat diantaranya: Berkaitan dengan persaingan yang tidak sehat antara sesama advokat seperti merebut klien dari teman seprofesi, memasang iklan, menjelek-jelekan, melakukan praktek curang seperti menggunakan data palsu, kolusi dengan pegawai pengadilan dan adanya penundaan waktu sidang dari pengadilan karena hakim berhalangan hadir juga menjadi hambatan dari advokat.

Dari uraian di atas dapat dilihat hambata-hambatan yang dialami advokat dalam memberikan jasa hukum kepada klien. Selain dari kendala di atas, dalam menggunakan jasa hukum juga menemui hambatan- hambatan dalam menggunakan jasa hukum dari advokat diantaranya:

a. Berkaitan dengan kualitas pelayanan yang diberikan kepada klien, seperti konspirasi dengan advokat lawan tanpa melibatkan klien

b. Menjanjikan kemenangan terhadapa klien

c. Mendiskriminasikan klien berdasarkan bayaran

Untuk mengatasi hambatan- hambatan tersebut, yang harus dilakukan advokat yaitu:

1. Menjelaskan kepada klien agar memberikan keterangan yang sebenarnya dan selengkap- lengkapnya agar advokat mengetahui duduk perkara yang sebenarnya.

2. Advokat memberitahukan pemahaman dan pengetahuan serta konsekuensi hukum tentang perkara tersebut. 
3. Menjaga kode etik advokat Indonesia sebagai landasan dalam menjalankan peranan dan fungsinya.

4. Meningkatkan kualitas pelayanan terhadap klien dengan tidak mendiskriminasikan klien. Bagi hakim kehadiran advokat di persidangan sangat membantu hakim dalam memutus suatu perkara, dengan kehadiran advokat dalam mewakili klien terhadap suatu perkara perdata dirasakan sangat membantu majelis hakim, dikarenakan advokat dibekali dengan ilmu dan ilmu hukum terutama beracara di Pengadilan. Namun demikian masih adanya kendala bagi hakim dari advokat dalam mewakili kliennya dikarenakan kurang keprofesionalnya advokat dalam menangani suatu perkara di Pengadilan.

\section{H. KESIMPULAN}

Berdasarkan hasil dan pembahasan yang telah dikemukakan sebelumnya maka dapat disimpulkan sebagai berikut :

1. Peranan advokat dalam memberikan jasa hukum dalam perkara perdata adalah bahwa Advokat sebagai penerima kuasa atau mewakili dari penggugat maupun tergugat dalam beracara di depan Pengadilan untuk menjelaskan dan meluruskan fakta-fakta serta bukti-bukti yang dikemukakan oleh kliennya, sehingga dapat membantu dan mempermudah hakim dalam mengambil suatu keputusan.

2. Hambatan hambatan yang dialami oleh Advokat dalam menjalankan perannya menyelesaikan perkara perdata bisa datangnya dari Internal maupun Eksternal. Dari internal antara lain kurangnya profesionalitas dari Advokat itu sendiri. Sedangkan dari eksternal dapat berupa klien yang tidak jujur dalam memberikan informasi atas perkara yang sedang dihadapinya/ masih ada yang ditutupi, klien ingkar janji untuk memenuhi honorarium/ fee yang telah disepakati dengan berbagai macam dalih/alas an, teman sejawat/ sesama advokat yang menjadi kuasa pihak lawan perkara tidak saling menghargai/menghormati.

\section{SARAN}

Berdasarkan apa yang telah penulis kerjakan dalam penelitian ini, maka penulis mencoba memberikan saran dan masukan atas hasil penelitian ini sebagai berikut:

1. Agar Advokat dalam memberikan jasa hukum berupa pembelaan perkara yang dihadapi diharapkan penasehat hukum selalu memberikan perhatian yang penuh 
terhadap perkara yang dibela, tanpa memperhatikan besarnya honorarium yang diterima, sehingga kehadiran advokat ditengah-tengah masyarakat sesuai dengan advokat sebagai profesi yang mulia dan bertindak berdasarkan keyakinan intelektualnya.

2. Agar klien dalam memberikan keterangan-keterangan tentang perkaranya kepada advokat selalu jujur dan terbuka tanpa ada yang ditutupi atau dirahasiakan, karena keterangan tersebut akan dapat membantu advokat dalam memberikan suatu pertimbangan hukum terhadap perkara yang dihadapi.

3. Agar advokat selalu menyarankan kepada klien supaya perkara yang dihadapi hendaknya dapat diselesaikan dengan cara musyawarah (non litigasi) karena perkara yang diselesaikan di Pengadilan waktunya lama dan mempunyai biaya yang besar.

\section{DAFTAR PUST AKA}

\section{Buku-Buku}

Adnan Buyung Nasution, (1982), Bantuan Hukum di Indonesia, Bantuan Hukum dan Politik Pembangunan, cet. Ke-1 Jakarta: LP3ES.

Ari Yusuf Amir,(2010), Strategi Bisnis Jasa Advokat, (Yogyakarta:Navila Idea)

Asasriwarni, (2002), Profesi Advokat : Peluang dan Tantangan Bagi Para Sarjana Syariah IAIN Imam Bonjol Padang

Bambang Kesowo,(2003)., Undang-Undang Advokat No. 18 Tahun 2003,Citra Umbara,Bandung

Bambang Soegono, (2002), Metode Penelitian Hukum, Raja Grafindo Persada, Jakarta.

Didi Kusnadi.,(2011)., Bantuan Hukum Dalam Hukum Islam., Kementerian Agama RI., Jakarta.

Frans Hendra Winarta. (2012).,Hukum Penyelesaian Sengketa. Jakarta: Sinar Grafika.

H Abdul Manan.,(2000)., Penerapan Hukum Acara Perdata di Lingkungan Peradilan Agama., Yayasan Al Hikmah., Jakarta.

Jeremias Lemek., (2007)., Mencari Keadilan., Galang., Jakarta.

Luhut M.P. Pangaribuan, (1996)., Advokat dan Contempt of Court, Penerbit Jambatan Jakarta.

Otto Hasibuan., (2007)., Kitab Advokat Indonesia., Peradi., Jakarta

Rahmad Rosyadi dkk, (1997), Advokat Dalam Persfektif Islam dan Hukum Positif. 
Rachmadi Usman. (2012). Mediasi di Pengadilan.., Sinar Grafika., Jakarta

Ropaun Rambe, (2001), Teknik Praktek Advokat, PT. Grasindo, Jakarta.

Rosadi dan Hartini, (2003)., Advokat Dalam Prespektif Islam,dan Hukum Positif., Ghalia Indonesia, Jakarta

Sartono dan Bhakti Suryani.,(2013)., Prinsip-prinsi Dasar Profesi Advokat., Dunia Cerdas., Jakarta.

Sudikno Mertokusumo, (1998), Hukum Acara Perdata Indonesia, Liberty, Yogyakarta.

Yuda Pandu, (2001), Klien dan Penasehat Hukum Dalam Presfektif Masa Kini, Jakarta.

WJS Poerwadarminta .(1976)., , Kamus Umum Bahasa Indonesia ., PN Balai Pustaka., Jakarta

(1976)., Kamus Umum Bahasa Inggris- Indonesia, IndonesiaInggri., PN Balai Pustaka., Jakarta.

\section{Peraturan Perundang-Undangan}

Undang-Undang Nomor 8 Tahun 1981 tentang Hukum Acara Pidana

Undang-Undang Nomor 18 Tahun 2003 tentang Advokat,

Undang-Undang Nomor 5 Tahun 2004 perubahan atas Undang- Undang

Nomor 14 Tahun 1985 tentang Mahkamah Agung

Undang-Undang Nomor 8 Tahun 2004 perubahan atas Undang- Undang Nomor 2 Tahun 1986 tentang Peradilan Umum

Undang-Undang Nomor 16 Tahun 2011 tentang Bantuan Hukum

Undang-Undang Nomor 30 Tahun 1999 tentang Arbitrase dan Alternatif Penyelesaian Sengketa

Kitab Undang-Undang Hukum Pidana (KUHPidana)

Peraturan Mahkamah Agung (PERMA) No. 1 Tahun 2008 tentang Prosedur Mediasi di Pengadilan. 